\title{
I come from
}

Dean Atta*

*Correspondence: infodeanatta@gmail.com

I come from shepherd's pie and Sunday roast,

jerk chicken and stuffed vine leaves.

I come from travelling through my taste buds but loving where I live.

I come from a home that some would call broken.

I come from D.I.Y. that never got done.

I come from waiting by the phone for him to call.

I come from waving the white flag to loneliness.

I come from the rainbow flag and the union jack.

I come from a British passport and an ever-ready suitcase.

I come from jet fuel and fresh coconut water.

I come from crossing oceans to find myself.

I come from deep issues and shallow solutions.

I come from a limited vocabulary but an unrestricted imagination.

I come from a decent education and a marvellous mother.

(c) Copyright: The Authors. This article is issued under I come from being given permission to dream but choosing to wake up the terms of the Creative Commons Attribution Noninstead.

Commercial Share Alike License, which permits use and redistribution of the work provided that the original author and source are credited, the work is not used for commercial purposes and that any derivative works are made available under the same license terms.

I come from wherever I lay my head.

I come from unanswered questions and unread books,

unnoticed effort and undelivered apologies and thanks.

I come from who I trust and who I have left.

I come from last year and last year and I don't notice how I've changed. 
I come from looking in the mirror and looking online to find myself.

I come from stories, myths, legends and folk tales.

I come from lullabies and pop songs, Hip Hop and poetry.

I come from griots, grandmothers and her-story tellers.

I come from published words and strangers' smiles.

I come from my own pen but I see people torn apart like paper, each a story or poem that never made it into a book.

To cite this article:

Atta, D. (2019) I Come From, Feminist Dissent, 4, pp. 158-159. Retrieved from: https://doi.org/10.31273/fd.n4.2019.410 